\title{
BETON POROUS DENGAN MENGGUNAKAN AGREGAT LOKAL DI KALIMANTAN SELATAN
}

\author{
Eka Purnamasari ${ }^{(1)}$ Fitria Handayani ${ }^{(2)}$ \\ (1) (2) Universitas Islam Kalimantan Muhammad Arsyad Al Banjari Banjarmasin \\ E-mail : eka.ftsuniska@gmail.com/HP.+6281257303768 \\ E-mail : fitria.ftsunika@gmail.com
}

\begin{abstract}
ABSTRAK
Dalam upaya mengantisipasi meningkatnya luas daerah yang ditutupi oleh perkerasan dengan pembangunan permukiman seperti halnya di perkotaan yang mengakibatkan waktu berkumpulnya air menjadi jauh lebih pendek, sehingga akumulasi air hujan yang terkumpul melebihi kapasitas drainase yang ada. Dengan berkurangnya kesempatan air hujan berinfiltrasi ke dalam tanah, maka limpasan permukaan air hujan akan menimbulkan genangan bahkan banjir pun dapat terjadi pula. Penelitian yang dilakukan menggunakan metode eksperimen, yaitu dengan menggunakan jenis agregat kasar lokal dari daerah dikalimantan selatan pada mix desain beton normal. Agregat kasar yang digunakan yaitu batu pecah dari handil bakti. Agregat dalam uji pendahuluan dengan proporsi perbandingan kerikil dan semen yaitu 4. Setelah diketahui proporsi yang tepat maka akan diuji dengan variasi FAS 0,3. Kemudian spesimen akan diuji dengan alat kuat tekan beton dengan metode hidraulic pump. Kuat tekan terjadi pada beton porous menggunakan agregat kasar batu pecah dari handil bakti yang diberikan perawatan perendaman dengan menggunakan air PDAM yaitu sebesar 6,22 MPa. Pola retakan yang terjadi dikarenakan penyebaran tegangan pada benda uji akibat proses ikat pegangan pada benda uji dan juga berpengaruh terhadap homogenitas agregat penyusun beton. Pada model yang dilakukan perawatan perendaman dengan air PDAM berdasarkan hasil penelitian pola retak yang terjadi yaitu retakan pada ujung samping (tipe 5). Daya rekat pasta terhadap agregat kasar baik, sedangkan agregat kasar yang berasal dari handil bakti terpecah- pecah menjadi potongan yang lebih kecil.
\end{abstract}

Kata Kunci: beton, porous, kuat tekan, kalimantan selatan

\begin{abstract}
In an effort to anticipate the increasing area of the region covered by the development of settlements as well as in urban areas that resulted in the time of gathering water becomes much shorter, so that the accumulated rainwater is accumulated exceeding the existing drainage capacity. With reduced chance of rainwater infiltration into the soil, then the runoff of the rain water will cause a puddle even flooding can also occur. Research conducted using the experimental method, namely by using the local rough aggregate type of the region under the southern area of the normal concrete design mix. The rough aggregate used is stone rupture of the Handil Bakti. Subtle aggregates in preliminary tests with the proportion of gravel and cement comparisons are 4. Once known proper proportions
\end{abstract}


it will be tested with variations of FAS 0.3. Then the specimen will be tested with a strong concrete press tool with the Hidraulic pump method. Strong press occurs on the porous concrete using a rough aggregate stone rupture of the Handil Bakti given soaking care with the use of PDAM water is 6.22 MPa. The cracking pattern occurs due to the dispersing of voltages in test objects due to the binding grip on the test objects and also affects the homogenity of the concrete constituent. In the model done soaking treatment with water PDAM based on the results of a crack pattern that occurs the cracks in the side end (Type 5). The adhesiveness of the pasta to the coarse aggregate is good, while the rough aggregate derived from Handil Bakti breaks down into smaller pieces.

Key word: concrete, porous, compressive strength, south Kalimantan

\section{PENDAHULUAN}

Sebagaimana pada beton konvensional, bahan utama penyusun beton berpori adalah semen portland, agregat, air dan bahan tambah lainnya dengan komposisi tertentu. Yang berbeda pada beton berpori adalah agregat yang digunakan hanya agregat kasar saja atau dengan sedikit sampai tidak ada agregat halus. Faktor air semen harus dijaga sedemikian rupa agar setelah mengeras pori-pori yang terbentuk tidak tertutup oleh campuran pasta semen yang mengeras. Selain kontrol pada faktor air semen juga bertujuan agar butir-butir agregat dapat terikat kuat satu sama lain untuk mendapat kuat tekan, kuat lentur, porositas, dan permeabilitas yang sesuai dengan karakteristik beton berpori. Beton berpori merupakan bahan jalan yang unik dan efektif yang ramah lingkungan. Dikatakan ramah lingkungan karena dengan menangkap air hujan dan membiarkan air hujan meresap kedalam tanah, material beton berpori dapat menolong mengisi cadangan air tanah, dan mengurangi limpasan permukaan.

Dengan diaplikasikan pada bahu jalan maka limpasan air dari jalan diharapkan akan terserap kedalam tanah, dan dapat terkuranginya debit air pada saluran drainase. Penggunaan beton konvensional yang terus meningkat mengakibatkan lapisan kedap air semakin luas, sehingga air hujan tidak dapat berinfiltrasi ke dalam tanah dan mengakibatkan limpasan permukaan (surface runoff) menjadi lebih besar. Hal ini mengakibatkan muka air tanah menjadi turun dan terjadi genangan atau banjir pada musim hujan.

Beton porous adalah jenis beton khusus dengan porositas tinggi yang diaplikasikan sebagai plat beton yang memungkinkan air hujan dan air dari sumber-sumber lain untuk dapat melewatinya, sehingga mengurangi limpasan permukaan dan meningkatkan muka air tanah. Porositas tinggi tercapai karena rongga yang saling berhubungan. Biasanya beton porous menggunakan sedikit atau tanpa agregat halus dan memiliki cukup pasta semen untuk melapisi permukaan agregat kasar dan untuk menjaga interkonektivitas pori. Beton porous secara tradisional digunakan untuk area parkir, di daerah lampu lalu lintas, dan trotoar untuk pejalan kaki (NRMCA, 2004). 
Beton porous memiliki banyak nama yang berbeda diantaranya adalah beton tanpa agregat halus (zero-fines concrete), beton yang dapat tembus (pervious concrete), dan beton berpori (porous concrete). Kuat tekan beton tanpa pasir lebih rendah dari kuat tekan beton normal konvensional karena peningkatan porositas. Kuat tarik dan kuat lentur beton tanpa pasir juga jauh lebih rendah dari beton konvensional (Abadjieva dan Sephiri, 2000).

Faktor air semen untuk beton non pasir bukan faktor utama untuk mengontrol sifat kekuatan. Faktor yang lebih penting adalah perbandingan agregat dengan semen. Ada suatu faktor air semen optimum yang memberikan kekuatan dan kepadatan maksimum. Penggunaan faktor air semen lebih tinggi dari 0,45 mengakibatkan pasta semen menjadi terlalu cair, dan akan mengalir meninggalkan agregat dan menyebabkan pengendapan pasta semen di dasar. Dengan faktor air semen yang lebih rendah dari 0,45 pasta tidak akan cukup untuk melapisi agregat. Faktor air semen optimum memungkinkan pasta semen untuk melapisi agregat secara seragam. Faktor air semen optimum untuk perbandingan agregat dengan semen 6:1 and 7:1 adalah sekitar 0,45 (Abadjieva dan Sephiri, 2000).

Untuk mengatasi endapan di bagian dasar beton porous akibat mengalirnya pasta semen perlu bahan pengisi pori antar agregat kasar yang masih memungkinkan air untuk menembus beton, dan penggunaan faktor air semen (fas) yang sekecil mungkin. Berdasarkan penelitian sebelumnya maka penelitian ini bertujuan untuk mengetahui kuat tekan dan perilaku beton porous dengan menggunakan agregat lokal yang berasal dari Kalimantan Selatan.

\section{METODE PENELITIAN}

Beton berpori yang juga dikenal sebagai pervious concrete atau porous concrete merupakan jenis beton yang memiliki pori-pori atau rongga pada strukturnya, sehingga memungkinkan cairan mengalir melalui rongga-ronnga yang terdapat pada beton. Menurut ACI 522R-10 Report on Pervious Concrete beton berpori dapat di deskripsikan sebagai beton yang memiliki nilai slump mendekati nol, yang terbentuk dari semen portland, agregat kasar, sedikit agregat halus atau tidak sama sekali, campuran tambahan (admixture), dan air.

Beton berpori bukanlah suatu jenis beton yang umum dipakai dalam suatu konstruksi dikarenakan oleh sifatnya yang berongga. Menjadikan aplikasi penggunaan beton berpori masih terbatas, bahkan di Indonesia sendiri masih kurang dirasakan.

Dikarenakan jenis konstruksi yang biasanya diandalkan untuk penyerapan air pada jalan adalah berbentuk paving block. Sifat berongga yang dimiliki oleh beton berpori membuat beton jenis ini memiliki kuat tekan lebih rendah dari pada jenis beton padat yang biasanya digunakan, sehingga membuat beton berpori lebih cocok untuk bila digunakan untuk aplikasi yang tidak membutuhkan nilai kuat tekan yang tinggi. Jenis stuktur yang dapat menggunakan beton berpori adalah lapangan parkir, lantai rumah kaca, perkerasan lapisan atas untuk taman, lapangan tenis, tempat pejalan kaki, dan juga sebagai perkerasan kaku untuk jalan lokal dengan intensitas lalulintas yang rendah. Sehingga secara garis besar beton berpori dapat diaplikasikan 
untuk jenis struktur yang tidak membutuhkan tulangan beton, karena dengan adanya tulangan pada beton berpori akan memberikan resiko karat pada tulangan yang disebabkan oleh cairan yang dapat menembus rongga beton.

Jika dilihat dari bentuknya beton berpori memiliki tekstur yang lebih kasar dari pada beton normal yang padat, dimana tekstur kasar ini dihasilkan oleh rongga yang ada pada beton. Jika digunakan untuk perkerasan, tekstur kasar dan berongga ini membuat perkerasan beton berpori memiliki suhu permukaan yang lebih rendah daripada perkerasan lentur dan juga perkerasan kaku normal dikarenakan luas permukaan penguapan yang ada lebih sedikit. Selain itu tekstur kasar juga membuat permukaan beton berpori menjadi lebih kesat dibandingkan dengan perkerasan normal.

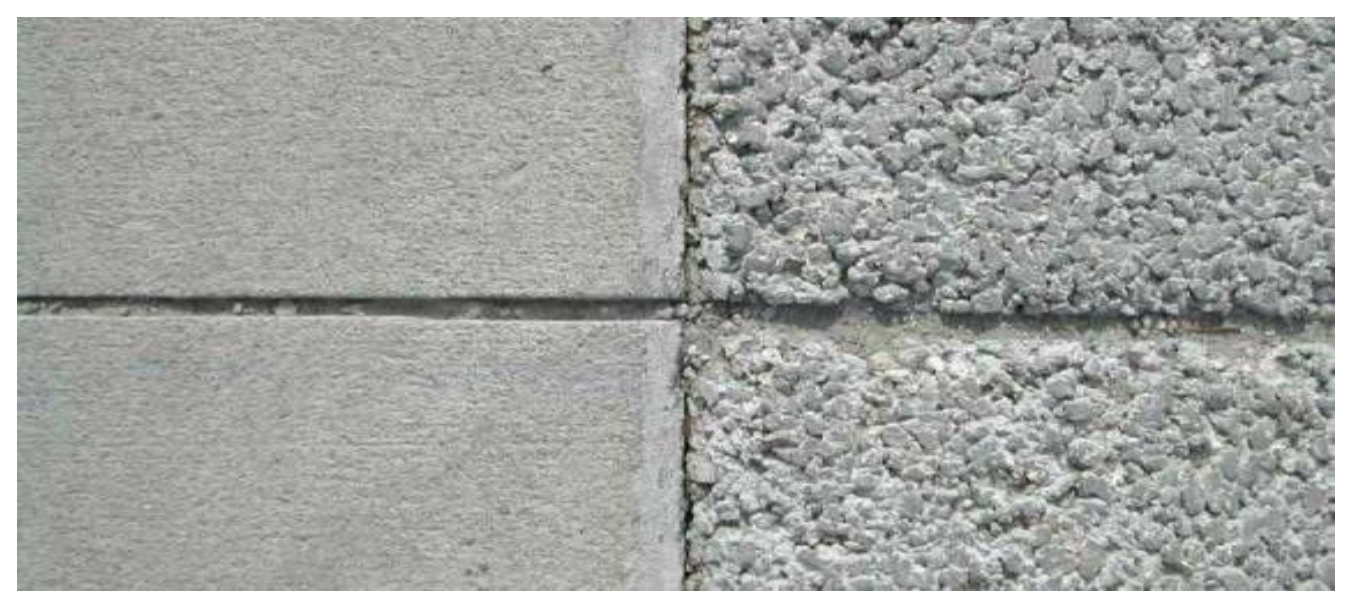

Gambar 1.Perbedaan Tekstur Permukaan Beton Berpori Dengan Beton Normal (Sumber: Florida Concrete \& Product Assosiation)

Keuntungan yang diapatkan dengan menggunakan beton berpori sebagai perkerasan adalah pengolahan air hujan lebih baik, beton berpori sebagai material konstruksi yang multifungsi selain berfungsi sebagai komponen struktural juga berfungsi sebagai saluran drainase air masuk ke dalam tanah sehingga mampu mengurangi limpasan permukaan.

Membantu menambah cadangan penyimpanan air tanah, dengan air hujan yang langsung mengalir ke dalam tanah maka akan membantu tanah dalam menambah cadangan air yang biasanya tidak terjadi pada perkerasan yang tidak tembus air. Mengurangi potensi banjir, penanganan air hujan membantu peresapan air lebih baik dimana lahan permukaan peresapan air ke dalam tanah menjadi lebih luas. Mengurangi penggunaan lahan untuk drainase, pemanfaatan lahan yang lebih efisien dengan mengurangi kebutuhan penyediaan kolam penyimpanan air hujan, selokan, dan sarana pengelolaan air hujan lainnya.

Mengurangi kelicinan pada jalan terutama pada saat hujan, permukaan yang lebih kasar dari perkerasan normal sangat membantu pada saat terjadinya hujan. Membantu peresapan air lebih baik ke tanah sehingga dapat mencapai 
akar pepohonan walau perkerasan menutupi pohon.

Dapat didaur ulang, tidak seperti pada beton konvensional, setelah mencapai umur rencana beton berpori dapat didaur ulang menjadi material beton berpori yang baru sehingga tidak menimbulkan limbahbuangan.

Instalasi yang lebih cepat, dimana proses pemasangan beton berpori akan lebih cepat selesai jika dibandingkan dengan pemasangan perkerasan bata beton. Rongga pada beton berpori dapat meredam kebisingan suara yang ditimbulkan oleh roda kendaraan, hal ini disebabkan karena pori-pori pada beton terbentuk secara tidak teratur dan memiliki permukaan yang tidak rata, sehingga gelombang suara yang dipantulkan secara baur oleh pori-pori pada beton menjadi saling bertumbukan dan saling meredam.

Mengurangi tingkat pencemaran terhadap air tanah, fungsi utama beton berpori adalah mengalirkan air yang ada di permukaan sehingga dapat diserap oleh tanah. Karena tidak menggunakan bahan kimia berbahaya di dalam campuran beton, maka potensi tercemarnya air tanah menjadi semakin kecil.

Dibandingkan dengan beton aspal dan perkerasan bata beton, perkerasan dengan menggunakan beton berpori memiliki keuntungan berjangka panjang. Walaupun biaya awal pada beton berpori lebih mahal dibandingkan dengan beton aspal, tetapi karena kekuatan dan daya tahan beton berpori yang lebih besar dibandingkan dengan aspal ataupun bata beton, maka menyebabkan biaya pemeliharaan yang diperlukan pada beton berpori selama umur rencana beton menjadi lebih kecil.

Kekurangan potensial yang dimiliki adalah:

1. Kurang baik digunakan untuk perkerasan yang membutuhkan kuat tekan besar atau lalulintas yang padat, hal ini dikarenakan oleh nilai kuat tekan beton berpori yang relatif kecil membuat aplikasi beton berpori sebagai perkerasan jalan sangat terbatas.

2. Dibutuhkan waktu proses curing yang lebih lama, dimana proses curing beton berpori harus dilakukan sesegera mungkin dari saat pengecoran dan baru selesai kurang lebih sekitar 7 hari.

3. Sensitif terhadap faktor air semen sehingga dibutuhkan kontrol air yang cermat karena untuk mengontrol kadar air beton berpori di lapangan sangatlah sulit, terlebih pada keadaan cuaca yang panas atau terlalu dingin.

4. Kurangnya standarisasi mengenai beton berpori dalam bidang pengujian, metode serta perencanaan di Indonesia.

5. Memiliki spesifikasi khusus dan cara instalasi khusus, sehingga dibutuhkannya tenaga yang sudah ahli dalam melakukannya menjadikan pengeluaran awal lebih mahal dari pada beton normal.

Seperti halnya beton normal komposisi yang digunakan untuk beton berpori tidak jauh berbeda, dimana material umum yang digunakan tetaplah semen, agregat, admixture dan air. Hal-hal yang harus diperhatikan dalam proses pembuatan beton berpori adalah: 


\section{Agregat}

Agregat adalah butir-butir batu pecah, kerikil, pasir, atau mineral lain, berasal dari alam maupun buatan yang berbentuk mineral padat berupa ukuran besar maupun kecil. Agregat sendiri merupakan komponen utama dari berbagai macam konstruksi, mulai dari konstruksi struktural yang menggunakan beton sampai dengan infrastruktur perkerasan jalan. Sebagai perkerasan, agregat sendiri berkisar $90-95 \%$ berdasarkan persentase berat keseluruhan dan $75-$ $85 \%$ dari persentase volume perkerasan. Sehingga kualitas dari pekerjaan struktur dan infrastruktur seperti beton dan perkerasan jalan ditentukan dari sifat agregat dan hasil campuran agregat dengan material lain. Pada campuran beton agregat digunakan sebagai bahan pengisi, untuk mengurangi penyusutan pada waktu beton mengeras (stabilitas volume), serta meningkatkan kekuatan dan keawetan dari beton.

Berdasarkan jenis pengolahannya agregat dibagi menjadi 2 jenis, yaitu agregat alam dan agregat olahan hasil pengolahan. Agregat alam adalah agregat yang dapat dipergunakan sebagaimana bentuknya di alam atau dengan sedikit proses pengolahan. Agregat ini terbentuk melalui proses erosi dan degradasi. Bentuk partikel dari agregat alam ditentukan proses pembentukannya. Dimensi agregat menjadi kecil biasanya dikarenakan oleh pelapukan batuan, contohnya adalah seperti kerikil dan pasir. Digunung- gunung atau dibukitbukit, dan sungai-sungai sering ditemui agregat yang masih berbentuk batu gunung, dan dalam ukuran yang besar sehingga diperlukan proses pengolahan terlebih dahulu sebelum dapat digunakan sebagai agregat konstruksi. Sehingga biasanya agregat-agregat dengan dimensi besar sepeti ini dihancurkan terlebih dahulu menjadi lebih kecil, biasanya agregat jenis ini disebut dengan batu pecah.

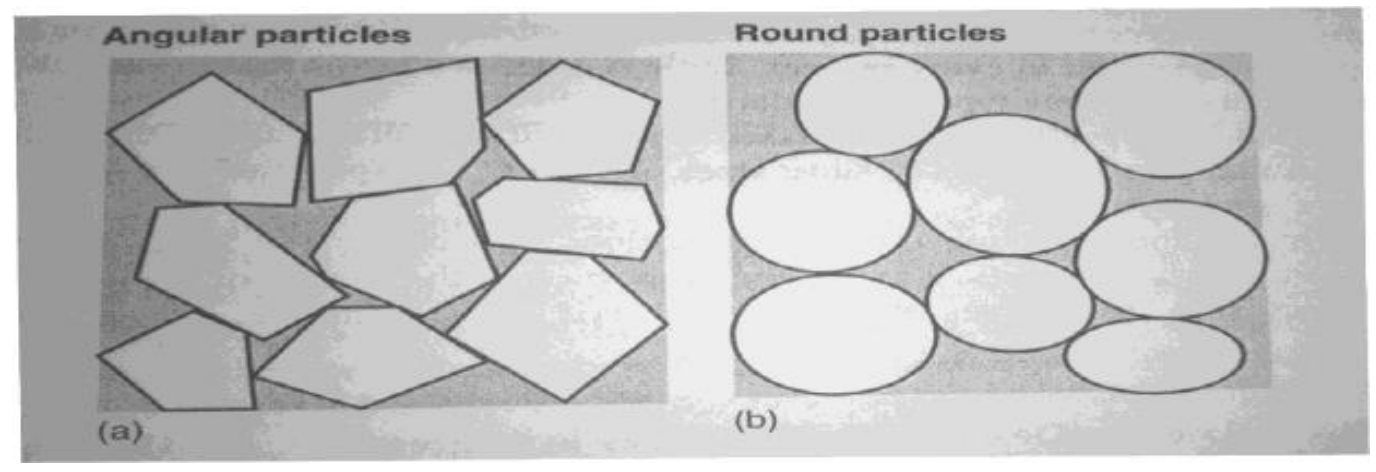

Gambar 2. (a) Batuan Kaku Dengan Sudut; (b) Batuan Bulat

(Sumber: Fergunson 2005)

Agregat yang baik untuk digunakan memiliki butiran keras tidak berpori serta bersifat kekal (tidak pecah terhadap pengaruh cuaca), selain itu juga tidak mengandung zat yang dapat merusak batuan. Agregat juga harus bersih dari debu atau tanah yang biasanya melekat pada agregat. Sehingga dibutuhkannya pemeriksaan terhadap agregat kasar yang akan digunakan sangatlah penting, 
karena kualitas dari agregat akan mempengaruhi kualitas beton. Kemudian berdasarkan gradasi penyebaran ukurannya, agregat dibagi menjadi 2 jenis, yaitu agregat dengan gradasi baik dan agregat dengan gradasi buruk.

a) Agregat dengan gradasi baik adalah campuran agregat dengan ukuran butiran yang terdistribusi merata dalam rentang ukuran butiran, agregat dengan gradasi baik sering juga disebut dengan agregat bergradasi rapat. Agregat dengan gradasi baik dapat didominasi oleh agregat dengan ukuran butiran kasar maupun halus. Dimana gradasi agregat yang didominasi oleh butiran kasar disebut agregat bergradasi kasar, dan agregat bergradasi halus bila gradasi agregat didominasi oleh agregat dengan butiran halus.

b) Agregat dengan gradasi buruk adalah distrubusi ukuran agregat yang tidak memenuhi persyaratan agregat bergradasi baik. Dimana agregat dengan gradasi buruk dibagi menjadi 3 jenis, yaitu:

- Gradasi Seragam, adalah campuran agregat yang tersusun dari agregat dengan ukuran butirannya sama atau hampir sama.

- Gradasi Terbuka, adalah campuran agregat dengan distribusi ukuran butiran sedemikian rupa sehingga pori-pori antar agregat tidak terisi dengan baik.

- Gradasi Senjang, adalah campuran agregat yang ukuran butirannya terdistribusi tidak menerus, atau ada bagian yang hilang.

Pada beton berpori sendiri jenis gradasi agregat yang digunakan biasanya adalah agregat dengan gradasi yang buruk, dimana agregat dengan gradasi buruk memiliki rongga-rongga antar tiap susunan agregatnya. Biasanya agregat kasar yang digunakan memiliki dimensi yang seragam (uniform) atau dapat juga dikombinasikan dengan agregat berdimensi lain dengan minimal dimensi $9 \mathrm{~mm}-5 \mathrm{~mm}$. Sedangkan untuk agregat halus pada beton berpori hanya digunakan sedikit atau tidak dipakai sama sekali. Untuk kualitas agregat sebaiknya digunakan yang baik, dimana agregat sebaiknya tidak berbentuk serpihan atau batuan yg pipih memanjang ataupun juga batuan yang berbentuk terlalu bulat.

\section{Semen}

Semen yang biasa digunakan adalah semen Portland yaitu semen hidrolik yang dihasilkan dengan menggiling klinker yang terdiri dari kalsium silikat hidrolik dan bahan tambahan berbentuk kalsium sulfat. Fungsi semen adalah untuk mempersatukan agregat kasar dan agregat halus menjadi satu kesatuan yang kuat setelah semen bereaksi dengan air. Semen yang dibutuhkan dalam pembuatan beton berpori sebaiknya dalam kondisi yang baik serta memenuhi standard SNI 15-2049-2004 mengenai semen Portland. Jenis semen yang digunakan adalah Portland Composite Cement (terlampir hasil uji semen).

\section{Air}

Kualitas air yang digunakan dalam campuran beton berpori tidak berbeda dengan beton normal, dimana air yang digunakan memiliki kualitas yang baik juga. Sesuai dengan persyaratan SNI 03-6817-2002, air yang dapat digunakan dalam proses pencampuran beton adalah sebagai berikut: 
a. Air yang digunakan pada campuran beton harus bersih dan bebas dari bahan- bahan yang merusak yang mengandung oli, asam, alkali, garam, bahan organik, atau bahan-bahan lainnya yang merugikan terhadap beton atau tulangan.

b. Air pencampur yang digunakan pada beton prategang atau pada beton yang di dalamnya tertanam logam aluminium, termasuk air bebas yang terkandung dalam agregat, tidak boleh mengandung ion klorida dalam jumlah yang membahayakan.

c. Air yang tidak dapat diminum tidak boleh digunakan pada beton, kecuali ketentuan berikut terpenuhi:

Pemilihan proporsi campuran beton harus didasarkan pada campuran beton yang menggunakan air dari sumber yang sama.

Hasil pengujian pada umur 7 dan 28 hari pada kubus uji yang dibuat dari adukan dengan air yang tidak dapat diminum harus mempunyai kekuatan sekurang-kurangnya sama dengan $90 \%$ dari kekuatan benda uji yang dibuat dengan air yang dapat diminum.

Faktor air semen berpengaruh sangat besar, dimana terlalu banyak air pada campuran akan mengakibatkan rongga-rongga pada beton berpori akan tertutup oleh pasta semen yang cair (bleeding). Sedangkan terlalu sedikit air akan membuat beton menjadi rapuh karena daya lekat semen dan antar agregat tidak sempurna, sehingga membuat ketahanan serta kuat tekan beton berpori menurun.

Pengaruh kurangnya air pada campuran beton berpori sangat dirasaan ketika proses pelepasan benda uji dari cetakan dilakukan, dimana beton berpori yang rapuh sangat mudah hancur ketika dilepas dari cetakannya. Sehingga air tidak dapat ditambahkan sembarangan saat pengadukan pasta beton, tetapi harus disesuaikan dengan kebutuhan dalam kemudahan pengerjaan serta mutu beton yang diinginkan.

Menurut ACI 522R-10 persentase faktor air semen yang paling baik dicapai oleh beton berpori pada 0,26 sampai dengan 0,45, dimana memberikan kondisi pasta yang stabil dan lapisan yang cukup merata pada agregat.

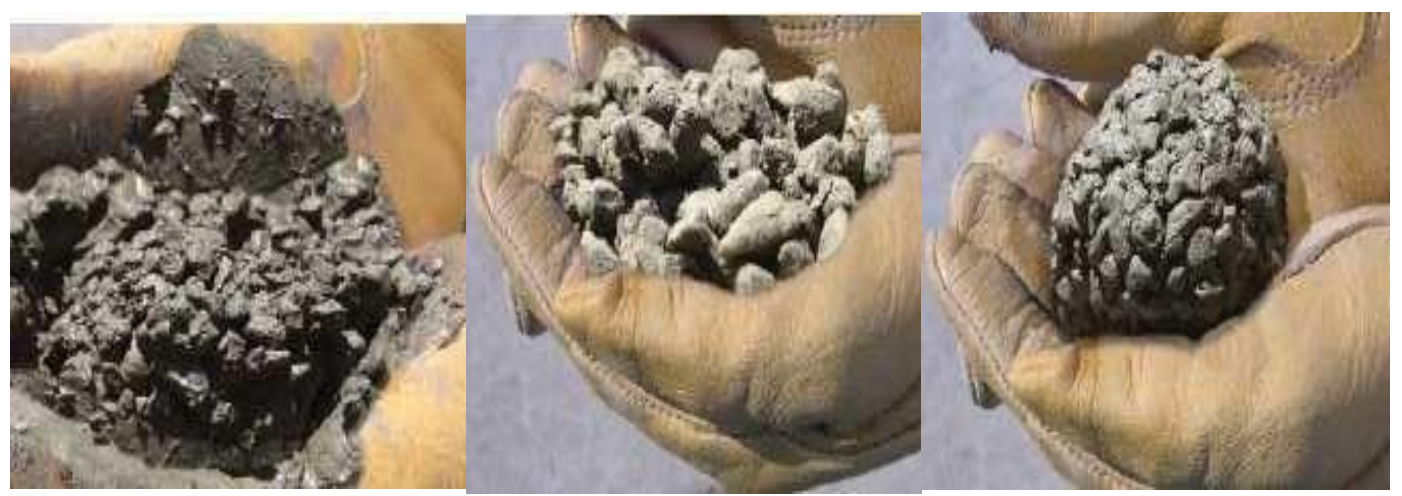

(a)

(b)

(c) 
Gambar 3. (a) Campuran Beton Kelebihan Air; (b) Campuran Beton Kekurangan Air; (c) Campuran Beton Deangan Jumlah Air yang Tepat (sumber: Pervious Concrete Pavements, Portland Cement Association)

Penelitian ini dilaksanakan dengan metode eksperimental yaitu dengan membuat benda uji beton porous yang menggunakan agregat lokal di kalimantan selatan. Agregat kasar yang digunakan yaitu batu pecah dari handil bakti, rasio agregat/semen adalah 4 dan faktor air semen 0,3. Tahap persiapan awal yaitu penyiapan bahan agregat lokal dari Kalimantan Selatan dalam penelitian ini digunakan agregat kasar batu pecah dari handil bakti serta persiapan alat dan bahan. Berikutnya dibuat campuran beton porous dengan komposisi rasio agregat/semen adalah 4 dan faktor air semen 0,3 . Setelah dilakukan pencetakan benda uji silinder sebanyak tiga buah maka dilakukan perawatan menggunakan air PDAM selama 28 hari. Pada saat benda uji berumur 28 hari maka siap untuk dilakukan uji kuat tekan beton porous. Sehingga dapat dianalisa kuat tekan dan perilaku dari beton porous yang menggunakan agregat lokal dari Kalimantan Selatan.

\section{HASIL \& PEMBAHASAN}

Sebelum dilakukan pembuatan benda uji dilakukan pengujian slump terlebih dahulu. Nilai slump untuk campuran beton porous dengan rasio agregat/ semen sebesar 4 dan dengan faktor air semen (fas) 0,30 adalah nol. Pembuatan benda uji silinder beton mengacu pada SNI 03-1974-1990.

Cetakan benda uji berupa silinder dengan diameter $152 \mathrm{~mm}$ dan tinggi $305 \mathrm{~mm}$. Cetakan diisi dengan adukan beton dalam 3 lapis, setiap lapis dipadatkan dengan 25 kali tusukan secara merata, setelah itu permukaan beton diratakan dan ditutup dengan bahan kedap air.

Perawatan beton adalah suatu pekerjaan menjaga agar permukaan beton selalu segar, lembab sampai beton dianggap cukup keras. Hal ini dimaksudkan untuk menjamin proses hidrasi semen berlangsung dengan sempurna. Selain itu perawatan juga mengurangi penyusutan akibat penguapan air berlebihan sehingga timbulnya retakan retakan dapat dihindari dan mutu beton tetap terjamin.

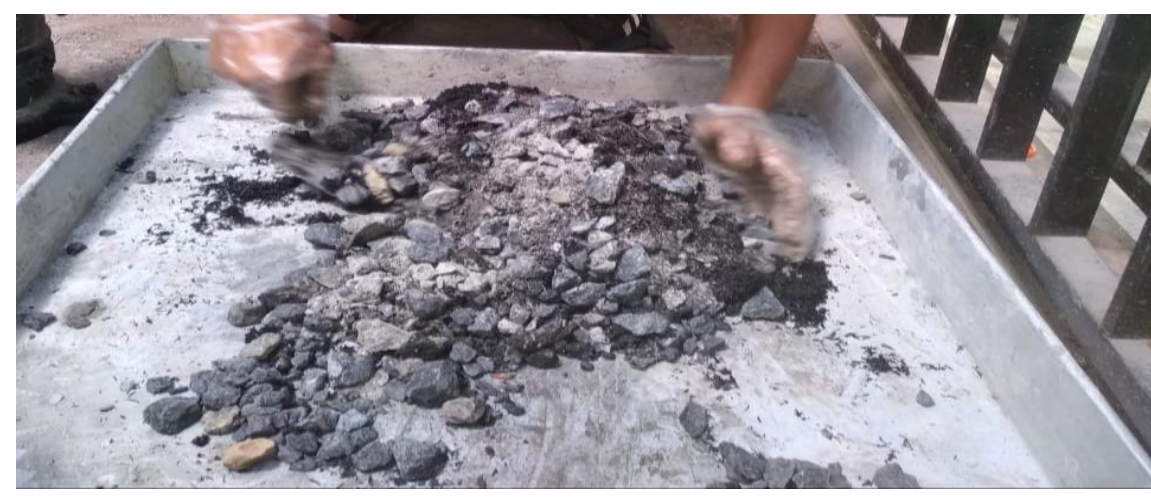

Gambar 4. Pembuatan Campuran Beton Porous 
Metode perawatan yang digunakan dalam penelitian ini adalah dengan cara direndam dalam bak perendam berisi air pada temperatur suhu ruangan. Perawatan dimulai pada hari kedua sampai satu hari sebelum dilakukan pengujian. Perawatan yang dilakukan pada penelitian ini menggunakan air PDAM.

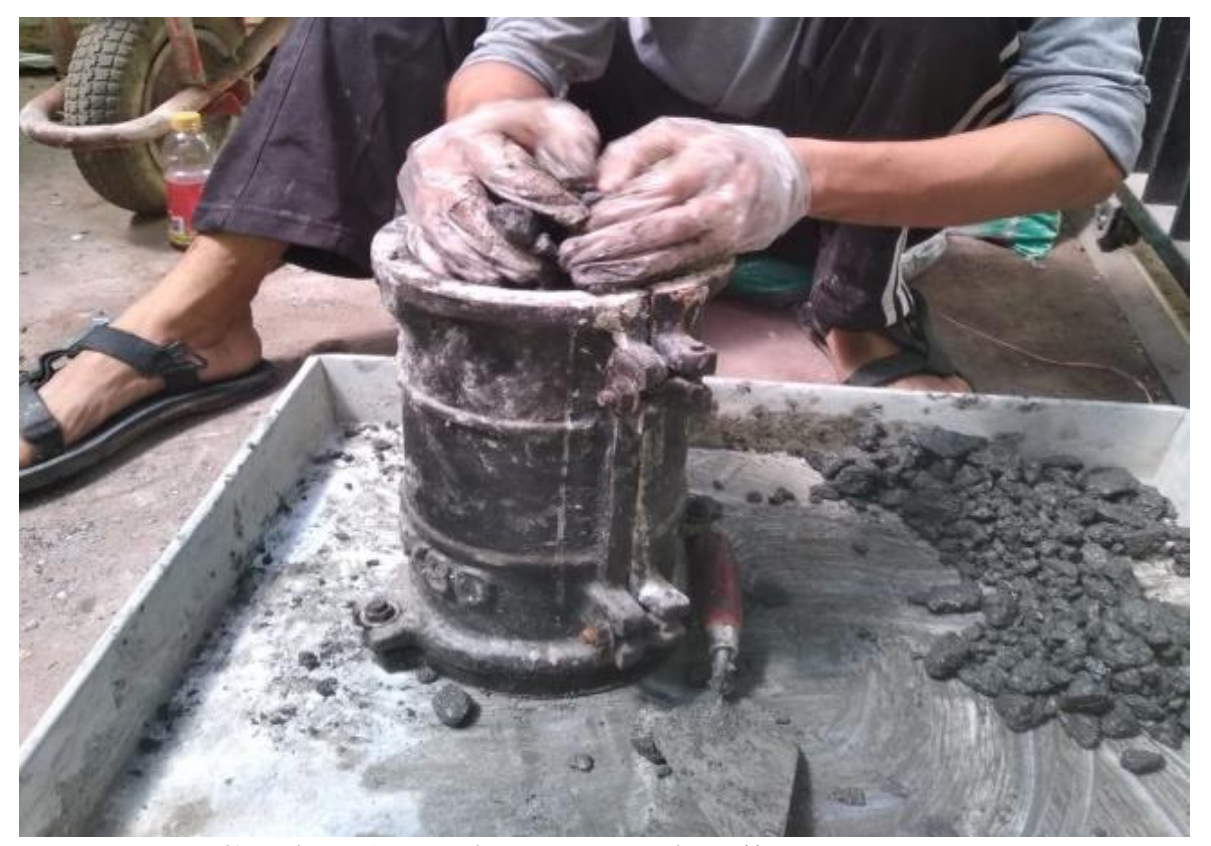

Gambar 5. Pembuatan Benda Uji Beton Porous

Dari hasil pengujian kuat tekan beton porous dengan perawatan perendaman dengan air PDAM selama 28 hari yaitu sebesar 6,22 MPa. Pola retak yang terjadi pada pengujian tekan statik beton ada berbagai macam menurut standar ASTM C 39/C 39M - 04a. Pola retakan yang terjadi dikarenakan penyebaran tegangan pada benda uji akibat proses ikat pegangan pada benda uji dan juga berpengaruh terhadap homogenitas agregat penyusun beton. Seperti terlihat pada gambar 3, pada model yang dilakukan perawatan perendaman dengan air PDAM berdasarkan hasil penelitian pola retak yang terjadi yaitu retakan pada ujung samping (tipe 5).

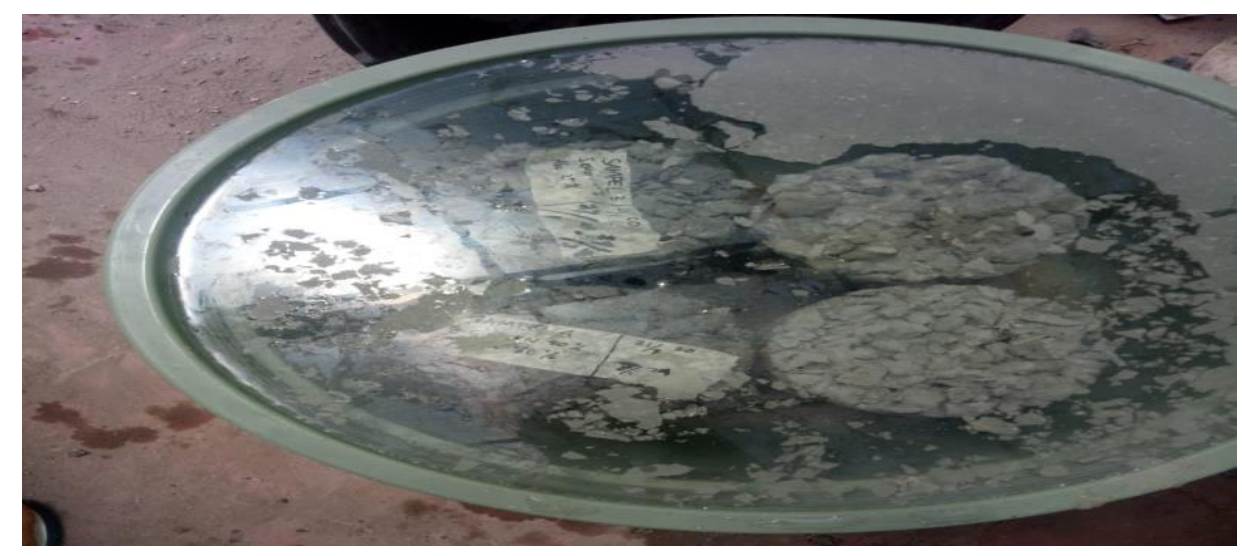

Gambar 6. Perawatan dengan Air PDAM 


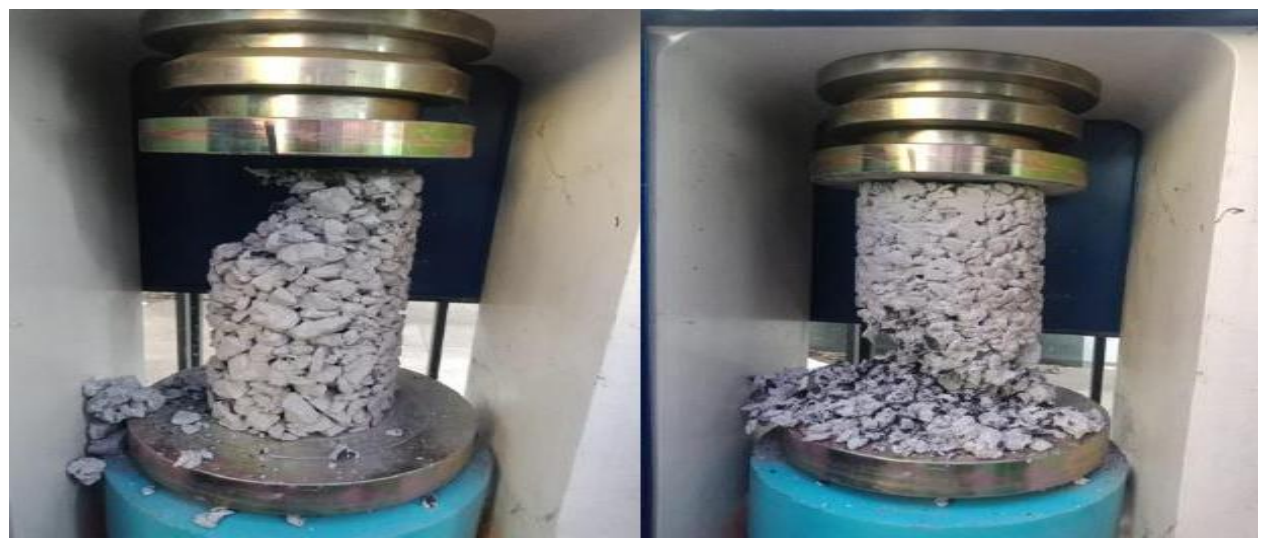

Gambar 7. Pengujian Kuat Tekan Beton Porous

Dari gambar diatas terlihat hancurnya agregat kasar dari handil bakti. Daya rekat pasta terhadap agregat kasar baik, sedangkan agregat kasar yang berasal dari handil bakti terpecah- pecah menjadi potongan yang lebih kecil.

\section{PENUTUP}

Kuat tekan terjadi pada beton porous menggunakan agregat kasar batu pecah dari handil bakti yang diberikan perawatan perendaman dengan menggunakan air DAM selama 28 hari yaitu sebesar 6,22 MPa. Pola retakan yang terjadi dikarenakan penyebaran tegangan pada benda uji akibat proses ikat pegangan pada benda uji dan juga berpengaruh terhadap homogenitas agregat penyusun beton. Pada model yang dilakukan perawatan perendaman dengan air PDAM berdasarkan hasil penelitian pola retak yang terjadi yaitu retakan pada ujung samping (tipe 5). Daya rekat pasta terhadap agregat kasar baik, sedangkan agregat kasar yang berasal dari handil bakti terpecah- pecah menjadi potongan yang lebih kecil.

\section{DAFTAR PUSTAKA}

Abadjieva, T., Sephiri, P., 2000, Investigations on Some Properties of No-Fines Concrete, University of Botswana, Botswana, http://www.irbnet.de/daten/iconda/CIB8837.pdf Anonim, 2004, CIP-38 Pervious Concrete, NRMCA (National Ready Mixed Concrete Association), Silver Spring, Maryland, http://www.nrmca.org/aboutconcrete/cips/38p.pdf

Anonim, 2010, ACI 522R-10, Repot on Pervious Concrete, American Concrete Institute, Farmington Hills, MI, USA.

Anonim, SNI 03-1974-1990, Metode Pengujian Kuat Tekan Beton, Puslitbang Permukiman, Departemen Pekerjaan Umum.

Cowd, M.A., 1991, Kimia Polimer, Penerbit ITB, Bandung.

Harber, P.J., 2005, Applicability of No-Fines Concrete as a Road Pavement, Research Project, Bachelor of Engineering, Faculty of Engineering and Surveying, University of Southern Queensland, https://eprints.usq.edu.au/472/1/PaulHARBER-2005.pdf

Neville, A.M., Brooks, J.J., 2010, Concrete Technology, Second Edition, Pearson Education Limited, Essex, England.

Tjokrodimuljo, K., 1996, Teknologi Beton, Buku Ajar, Jurusan Teknik Sipil, Fakultas Teknik, Universitas Gadjah Mada, Yogyakarta. 